\title{
OPTIMIZATION OF THE USED SUNFLOWER OIL METHANOLYSIS CATALYZED BY HAZELNUT SHELL ASH
}

Milica Petković1 ${ }^{\text {, Marija Miladinović }}{ }^{3}$, Ivana Banković-llić ${ }^{\star}$, Olivera Stamenković2 Vlada Veljković2,4

\footnotetext{
${ }^{1}$ Scholar of the Ministry of Education, Science and Technological Development of the Republic of Serbia

2 Faculty of Technology, University of Niš, Leskovac, Serbia

${ }^{3}$ Faculty of Agriculture, University of Niš, Kruševac, Serbia

${ }^{4}$ The Serbian Academy of Sciences and Arts, Belgrade, Serbia
}

The methanolysis of used sunflower oil catalyzed by hazelnut shell ash was studied to evaluate the statistical significance of the process factors, i.e., the initial methanol-to-oil molar ratio, the catalyst amount, and the reaction time on fatty acid methyl ester (FAME) content and to determine their optimal values ensuring the highest FAME content. The reaction was conducted in a batch reactor at the methanol-to-oil molar ratios of $6: 1-18: 1$, the catalyst amounts of $1-5 \%$ (of the oil weight), and the reaction time of $10-50 \mathrm{~min}$. Furthermore, statistical modeling and optimization were performed using a modified second-order polynomial model developed by the response surface methodology in combination with a $3^{3}$ factorial design with three central points. The analysis of variance showed that all three factors, the two-parameter interaction of the catalyst amount and the reaction time, as well as the quadratic term of the reaction time, had a statistically significant effect on FAME content. The optimum conditions were found to be the methanol-to-oil molar ratio of $10.34: 1$, the catalyst amount of $5 \%$, and the reaction time of $34 \mathrm{~min}$. The predicted value of FAME content was $99.63 \%$, which agreed well with the experimentally determined FAME content (97.15\%).
(ORIGINAL SCIENTIFIC PAPER) UDC 662.756.3:66.011

DOI 10.5937/savteh2102032P

Keywords: biodiesel; hazelnut shell; modeling, optimization, response surface methodology

\section{Introduction}

The depletion of the world's fossil fuel reserves and growing concern for the environment has stimulated the search for alternative renewable fuels, which can meet growing energy needs in the world. In recent decades, research and knowledge on renewable raw materials have intensified efforts to use sustainable energy sources, where biodiesel plays a major role. As a very good alternative to petroleum diesel, the use of biodiesel has a number of advantages. Some of them refer to biodiesel's renewability, biodegradability, and low toxicity, as well as reduced harmful emissions and improved engine combustion; the additional benefits are the improvement of the rural economy, the use of existing diesel engines without or with minor modifications, blending with petroleum-based diesel fuel, etc. $[1,2]$. However, there are some disadvantages of the production and application of biodiesel, such as the use of edible oils as feedstocks, high production costs, corrosion of the equipment, lower engine power, higher viscosity, and lower volatility compared to diesel, etc. [3]. Therefore, to improve the economy of a biodiesel production process, more research is focused on the possible use of cheap raw materials and catalysts obtained from non-edible, waste, and natural materials.

Chemically, biodiesel is the mixture of fatty acid alkyl esters, obtained by the alcoholysis of triacylglycerols (TAGs) from oily raw materials with alcohol (methanol or ethanol) in the absence or presence of a catalyst (base, acid, or enzyme). Edible oils like rapeseed, sunflower, soybean, and palm are common raw materials for biodiesel production due to their availability in large quantities and high biodiesel yields that can be achieved by the existing technological processes. However, due to their use in human nutrition, edible oils are expensive feedstocks for biodiesel production. The use of low-cost non-edible oily resources, such as jatropha, karanja, tobacco, mahua, neem, rubber, sea mango, castor, cotton, etc. [4], and waste cooking oils [5] can significantly reduce the cost of biodiesel production.

Besides numerous advantages of homogeneous catalysts, they can be corrosive and are difficult to separate from the products. Heterogeneous catalysts are, however, easily separable from the reaction mixture. Various compounds have been used as heterogeneous catalysts in biodiesel production processes, such as alkaline metal hydroxides and alkoxides, alkaline earth metal oxides, hydroxides and alkoxides, metal salts, zeolites, ion exchange resins, Mg-Al hydrotalcites, impregnated salts of alkali metals, alkylguanidines, and metals [6]. In the last decade, food processing waste

\footnotetext{
*Author address: Ivana Banković-llić, Faculty of Technology, University of Niš,

Bulevar oslobođenja 124, 16000 Leskovac, Serbia

e-mail address: ivanabank@yahoo.com

The manuscript received: September, 16, 2021.

Paper accepted: October, 29, 2021.
} 
materials, such as cockle shells [7], eggshells [8, 9], and animal bones [10, 11], as well as the ashes obtained by combustion of biomass, such as wood [12], banana [13], pineapple [14], sugarcane leaves [15], wheat bran [16], walnut shell [17], etc., which are rich in $\mathrm{K}, \mathrm{Si}, \mathrm{Ca}, \mathrm{Mg}, \mathrm{Al}, \mathrm{S}, \mathrm{Fe}, \mathrm{P}, \mathrm{Na}$ and $\mathrm{Ti}$, have been successfully used as solid catalysts in biodiesel production. Thus, hazelnut shell ash contains $30.6 \% \mathrm{~K}_{2} \mathrm{O}$, $29.4 \% \mathrm{SiO}_{2}, 18.2 \% \mathrm{CaO}$ and $8.6 \% \mathrm{MgO}$ [18] indicating its good catalytic properties, but there are no data in the literature on the use of hazelnut shell ash as a heterogeneous catalyst for biodiesel production.

The statistical methods are widely used for modeling and optimizing biodiesel production processes and assessing the statistical significance of the influential process factors (like initial methanol-to-oil molar ratio, catalyst amount, reaction temperature, and time) on the desired response (ester content or yield). The response surface methodology (RSM), combined with the full $3^{3}$ factorial design $[19,20]$, central composite design (CCD) [21], or Box-Behnken design (BBD) [22], has been most frequently applied procedure for the statistical analysis of batch biodiesel production processes. The second-order polynomial equation is commonly used to relate ester content to the process factors. In this way, it is possible to evaluate the statistical significance of the process factors and their interactions using analysis of variance (ANOVA) and the optimal levels of the process factors.

In this paper, the biodiesel production involving used sunflower oil (USO) as an oily feedstock and hazelnut shells ash as a solid catalyst, was investigated. The aim of the study was to determine the statistical significance of the influential methanolysis reaction conditions (initial methanol-to-oil molar ratio, catalyst amount, and reaction time) on ester content and the optimal reaction conditions to achieve a maximum ester content using the RSM coupled with a $3^{3}$ factorial design with three central points. This can have practical significance for increasing the efficiency of the biodiesel production process and reducing its costs.

\section{Experimental}

\section{Materials}

USO (acid number 0.54 mg KOH/g, Dijamant, Zrenjanin, Serbia) and methanol (purity of 99.5\%, Zorka Pharma, Šabac, Serbia) were used as the reactants. Methanol, 2-propanol, and $n$-hexane, HPLC grade, were from Lab-Scan (Dublin, Ireland) while the standards of a mixture of methyl esters of palmitic, stearic, oleic, linoleic, and linolenic acids ( $20 \%$ of each), monoolein, diolein, and triolein were purchased from SigmaAldrich (St. Louis, USA).

Hazelnuts were collected at the location of southern Serbia. To get ash, hazelnut shells were burned in the open air. The obtained biochar was then ground, calcinated for $2 \mathrm{~h}$ at $800{ }^{\circ} \mathrm{C}$, cooled, and stored in a well-closed glass container in a desiccator in the presence of $\mathrm{KOH}$ pellets. Other authors have applied the combustion of hazelnut shells by pyrolysis in a muffle furnace at $300-550{ }^{\circ} \mathrm{C}$ [23], or in a lab-scale reactor at $800{ }^{\circ} \mathrm{C}[24,25]$, but a large weight loss was observed during the process due to the decomposition of hemicelluloses, celluloses, and lignin [24].

\section{USO methanolysis}

The USO methanolysis catalyzed by hazelnut shell ash was conducted at a temperature of $60^{\circ} \mathrm{C}$ while stirring the reaction mixture of $800 \mathrm{rpm}$ under atmospheric pressure. The initial methanol-to-oil molar ratio, the catalyst amount, and the reaction time were in the ranges of $6: 1-18: 1,1-5$ wt.\% (of the oil mass), and 10-50 min, respectively.

The reaction was performed in a three-necked glass round-bottomed flask $(250 \mathrm{~mL})$, equipped with a reflux condenser and a magnetic stirrer. The reactor was placed in a glass chamber filled with water, which was circulated from a thermostated bath by means of a centrifugal pump to maintain a constant temperature $\left(60 \pm 0.1^{\circ} \mathrm{C}\right)$. The predetermined amounts of methanol and catalyst were poured into the reactor and thermostated at the desired reaction temperature for $30 \mathrm{~min}$ with stirring (500 rpm). The required mass of USO was thermostated separately at the same temperature, the magnetic stirrer was stopped, and the preheated USO was added to the mixture of methanol and catalyst in the reactor. The samples of the reaction mixture were periodically taken during the reaction, immersed in the ice water to stop the reaction, immediately centrifuged (Sigma Laborcentrifugen 2-6E, Germany) for $10 \mathrm{~min}$ at $3500 \mathrm{rpm}$ to separate the solid catalyst particles, and analyzed.

The upper methyl ester layer was withdrawn, dissolved in a solution of 2-propanol and n-hexane (5/4, $\mathrm{v} / \mathrm{v}$ ) in the ratio of $1: 200$, and filtered through a 0.45 $\mu \mathrm{m}$ Millipore filter. The filtrate was analyzed using liquid chromatograph (Agilent 1100 Series) to determine its quantitative composition [26].

\section{Optimization study}

To assess the impact of the reaction conditions on FAME content, the RSM combined with a factorial plan $3^{3}$ with three central points was applied in the optimization study. The following process factors (independent variables) were optimized: the initial methanol-to-oil molar ratio $\left(X_{1}\right)$, the amount of catalyst $\left(X_{2}\right)$, and the reaction time $\left(\mathrm{X}_{3}\right)$. The low, central, and high coded levels of the process factors are denoted as $(-1),(0)$, and (1), respectively (Table 1 ). The dependent variable (system response) was FAME content achieved under the defined reaction conditions. The experimental matrix with coded and uncoded levels of the process variables and obtained FAME contents are given in Table 2. Experiments were randomly performed to avoid errors that may occur due to the influence of the external factors 
(noise) on FAME content. The statistical significance of all the factors and their interactions was assessed based on $F$ - (Fisher's test) and $p$-values. The higher $F$ value of factor and the lower $p$-value indicate the higher significance level of the model for fitting the experimen- tal data. If the $p$-values are lower than 0.05 , the factors and their interactions are significant at the confidence level of $95 \%$. When the $p$-values are greater than 0.05 , then the factors and their interactions have no statistically significant effect on FAME content.

Table 1. Experimental range and levels of each process factor

\begin{tabular}{llccc}
\hline Factor & Label & Low level (-1) & Central level (0) & High level (1) \\
\hline $\begin{array}{l}\text { Initial methanol-to-oil molar ratio } \\
\text { (mol/mol) }\end{array}$ & $\mathrm{X}_{1}$ & $6: 1$ & $12: 1$ & $18: 1$ \\
Amount of catalyst (\%) & $\mathrm{X}_{2}$ & 1 & 3 & 5 \\
Reaction time (min) & $\mathrm{X}_{3}$ & 10 & 30 & 50 \\
\hline
\end{tabular}

Table 2. The matrix of experiments: factorial plan $3^{3}$ with three central points

\begin{tabular}{|c|c|c|c|c|c|c|c|}
\hline \multirow{2}{*}{ Run } & \multicolumn{3}{|c|}{ Coded factors } & \multicolumn{3}{|c|}{ Uncoded factors } & \multirow{2}{*}{$\begin{array}{c}\text { Response } \\
\text { FAME content, } Y(\%)\end{array}$} \\
\hline & $x_{1}$ & $X_{2}$ & $X_{3}$ & $x_{1}$ & $x_{2}$ & $X_{3}$ & \\
\hline 1 & -1 & -1 & -1 & 6 & 1 & 10 & 31.77 \\
\hline 2 & 0 & -1 & -1 & 12 & 1 & 10 & 39.31 \\
\hline 3 & 1 & -1 & -1 & 18 & 1 & 10 & 32.99 \\
\hline 4 & -1 & 0 & -1 & 6 & 3 & 10 & 49.92 \\
\hline 5 & 0 & 0 & -1 & 12 & 3 & 10 & 44.96 \\
\hline 6 & 1 & 0 & -1 & 18 & 3 & 10 & 54.27 \\
\hline 7 & -1 & 1 & -1 & 6 & 5 & 10 & 73.81 \\
\hline 8 & 0 & 1 & -1 & 12 & 5 & 10 & 82.65 \\
\hline 9 & 1 & 1 & -1 & 18 & 5 & 10 & 75.65 \\
\hline 10 & -1 & -1 & 0 & 6 & 1 & 30 & 73.08 \\
\hline 11 & 0 & -1 & 0 & 12 & 1 & 30 & 74.62 \\
\hline 12 & 1 & -1 & 0 & 18 & 1 & 30 & 87.22 \\
\hline 13 & -1 & 0 & 0 & 6 & 3 & 30 & 79.87 \\
\hline 14 & 0 & 0 & 0 & 12 & 3 & 30 & 91.08 \\
\hline 15 & 1 & 0 & 0 & 18 & 3 & 30 & 97.87 \\
\hline 16 & -1 & 1 & 0 & 6 & 5 & 30 & 94.92 \\
\hline 17 & 0 & 1 & 0 & 12 & 5 & 30 & 98.57 \\
\hline 18 & 1 & 1 & 0 & 18 & 5 & 30 & 98.92 \\
\hline 19 & -1 & -1 & 1 & 6 & 1 & 50 & 74.32 \\
\hline 20 & 0 & -1 & 1 & 12 & 1 & 50 & 88.95 \\
\hline 21 & 1 & -1 & 1 & 18 & 1 & 50 & 95.14 \\
\hline 22 & -1 & 0 & 1 & 6 & 3 & 50 & 88.06 \\
\hline 23 & 0 & 0 & 1 & 12 & 3 & 50 & 95.31 \\
\hline 24 & 1 & 0 & 1 & 18 & 3 & 50 & 98.40 \\
\hline 25 & -1 & 1 & 1 & 6 & 5 & 50 & 96.42 \\
\hline 26 & 0 & 1 & 1 & 12 & 5 & 50 & 98.52 \\
\hline 27 & 1 & 1 & 1 & 18 & 5 & 50 & 98.99 \\
\hline 28 & 0 & 0 & 0 & 12 & 3 & 30 & 90.25 \\
\hline 29 & 0 & 0 & 0 & 12 & 3 & 30 & 92.04 \\
\hline 30 & 0 & 0 & 0 & 12 & 3 & 30 & 91.56 \\
\hline
\end{tabular}


A multiple regression model corresponding to the second-order polynomial equation was applied in the analysis of the experimental data. The general regression equation of this model that correlates FAME content with the process factors is as follows:

$Y=b_{0}+b_{1} X_{1}+b_{2} X_{2}+b_{3} X_{3}+b_{12} X_{1} X_{2}+b_{13} X_{1} X_{3}+$

$+b_{23} X_{2} X_{3}+b_{123} X_{1} X_{2} X_{3}+b_{11} X_{1}^{2}+b_{22} X_{2}^{2}+b_{33} X_{3}^{2}$

where $Y$ is the FAME content, $b_{0}$ is the constant regression coefficient, $b_{i}$ and $b_{i i}$ are the linear and quadratic regression coefficients, respectively and $b_{i j}$ are the regression coefficients of the two-factor interactions $(i$, $j, k=1,2,3$ ) while $X_{i}$ is the process factor.

The obtained experimental data were analyzed by a Design Expert software (a trial version). The statistical significance of the process factors and their interactions, as well as the applicability of the model to fit the experimental data, were determined by the analysis of variance (ANOVA). The influence of the process factors on FAME content was assessed by the RSM, and the optimal reaction conditions for achieving the maximum FAME content were determined by solving the developed regression equation.

\section{Results and discussion}

Analysis of variance (ANOVA)

The ANOVA results (Table 3a) showed a statistical significance of the methanol-to-oil molar ratio, the catalyst amount, and the reaction time, as well as the two-parameter interaction of the catalyst amount and the reaction time and the quadratic term of the reaction time on FAME content. Based on the F-value of the individual factors, the reaction time had the greatest statistical effect, followed by the amount of catalyst, while the methanol-to-oil molar ratio had a much smaller effect. On the other hand, the interactions of the methanol-to-oil molar ratio with the amount of catalyst and the reaction time, their three-parameter interaction, and the squares of the methanol-to-oil molar ratio and the amount of catalyst did not have a statistically significant effect on FAME content. The ANOVA results for the reduced second-order regression model are shown in Table 3b.

Table 3a. ANOVA results for the second-order regression model

\begin{tabular}{lccccc}
\hline Source & $\begin{array}{c}\text { Sum of } \\
\text { squares }\end{array}$ & df & Mean square & F-value & $p$-value \\
\hline Model & 12522.08 & 10 & 1252.21 & 66.51 & $<0.0001$ \\
$X_{1}$ & 331.79 & 1 & 331.79 & 17.62 & 0.0005 \\
$X_{2}$ & 2714.62 & 1 & 2714.62 & 144.18 & $<0.0001$ \\
$X_{3}$ & 6758.19 & 1 & 6758.19 & 358.94 & $<0.0001$ \\
$X_{1} X_{2}$ & 64.26 & 1 & 64.26 & 3.41 & 0.0803 \\
$X_{1} X_{3}$ & 57.73 & 1 & 57.73 & 3.07 & 0.0961 \\
$X_{2} X_{3}$ & 713.33 & 1 & 713.33 & 37.89 & $<0.0001$ \\
$X_{1}{ }^{2}$ & 25.34 & 1 & 25.34 & 1.35 & 0.2604 \\
$X_{2}{ }^{2}$ & 1.38 & 1 & 1.38 & 0.07 & 0.7892 \\
$X_{3}{ }^{2}$ & 1672.81 & 1 & 1672.81 & 88.85 & $<0.0001$ \\
$X_{1} X_{2} X_{3}$ & 44.51 & 1 & 44.51 & 2.36 & 0.1407 \\
Lack of fit & 355.99 & 16 & 22.25 & 38.19 & 0.0060 \\
Pure error & 1.75 & 3 & 0.58 & & \\
Corrected total & 12879.82 & 29 & & & \\
\hline
\end{tabular}

Table 3b. ANOVA results for the reduced second-order regression model

\begin{tabular}{lccccc}
\hline Source & $\begin{array}{c}\text { Sum of } \\
\text { squares }\end{array}$ & df & Mean square & F-value & $\boldsymbol{p}$-value \\
\hline Model & 12330.03 & 5 & 2466.01 & 107.65 & $<0.0001$ \\
$X_{1}$ & 331.79 & 1 & 331.79 & 14.48 & 0.0009 \\
$X_{2}$ & 2714.62 & 1 & 2714.62 & 118.50 & $<0.0001$ \\
$X_{3}$ & 6758.19 & 1 & 6758.19 & 295.02 & $<0.0001$ \\
$X_{2} X_{3}$ & 713.33 & 1 & 713.33 & 31.14 & $<0.0001$ \\
$X_{3}{ }^{2}$ & 1812.1 & 1 & 1812.1 & 79.10 & $<0.0001$ \\
Lack of fit & 548.04 & 21 & 26.09 & 44.79 & 0.0047 \\
Pure error & 1.748 & 3 & 0.58 & & \\
Corrected total & 12879.82 & 29 & & & \\
\hline
\end{tabular}


In the case of the methanolysis of Bauhinia monandra oil catalyzed by banana peel ash, a positive effect of the methanol-to-oil molar ratio, catalyst amounts, and two-parameter interactions of all factors on FAME content was observed, while the reaction time and the square of reaction time were not statistically significant [20]. Along with the catalyst amount and methanol-tooil molar ratio, the reaction temperature had a significant effect on FAME yield in the methanolysis of $\mathrm{Ca}$ lophyllum inophyllum oil over sugarcane leaf ash as a solid catalyst while the influence of the reaction time was not investigated [15]. The reaction time and catalyst amount did not have a statistically significant effect on FAME content in the corn oil methanolysis catalyzed by corn cob ash [19]. The significant effect of the catalyst amount on FAME yield was observed in the rubber seed oil methanolysis over a catalyst prepared by loading on activated carbon [27]. However, Kostić et al. [19] found that the influence of the catalyst amount obtained by calcination of palm kernel shell biochar on FAME content was not statistically significant.

Mathematical modeling of the process using the multiple regression method

Based on the ANOVA results (Table 3a), the secondorder model, Equation 1, can be reduced by removing the statistically insignificant terms in the following modified equation:

$Y=b_{0}+b_{1} X_{1}+b_{2} X_{2}+b_{3} X_{3}+b_{23} X_{2} X_{3}+b_{33} X_{3}^{2}$

The developed regression model with coded and uncoded factors is given by Equations 3 and 4, respectively:

$Y=89.17+4.29 \cdot X_{1}+12.28 \cdot X_{2}+19.38 \cdot X_{3}-7,71 \cdot X_{2} X_{3}-15.86$ $X_{3}^{2}$.

$Y=-19.95+0.72 \cdot X_{1}+11.92 \cdot X_{2}+3.93 \cdot X_{3}-0.19 \cdot X_{2} X_{3}-0.04$ $\cdot X_{3}^{2}$

The positive regression coefficients of Equation 3 indicate the process factors that favorably influence the FAME content. The interaction of the catalyst amount and the reaction time, as well as the quadratic term of the reaction time, has an antagonistic effect on the FAME content due to the stronger influence of the individual process factors.

The validity of the developed model was assessed using the $F_{\text {model }}$ and $p_{\text {model }}$ - values, the coefficient of determination $\left(R^{2}\right)$, the adjusted coefficient of determination (adj. $R^{2}$ ), the predicted coefficient of determination (pred. $R^{2}$ ), and the coefficient of variation (C.V.). The $F_{\text {mode }}{ }^{-}$and $p_{\text {model }}{ }^{-}$values (Table $3 \mathrm{~b}$ ) indicate that the model is statistically significant within $95 \%$ of the confidence level. Having high values of $R^{2}(0.957)$ and adj. $R^{2}(0.948)$, the model can be used to predict the FAME content with good accuracy. The $R^{2}$-value of 0.957 indi- cates that $95.7 \%$ of the variations in the FAME content can be explained by the regression model while $4.3 \%$ of these variations were the result of other uncontrolled factors. An acceptable agreement between the pred. $R^{2}$ (0.929) and the adj. $R^{2}(0.948)$ indicated that the model achieved a good data fit and estimated FAME content reliably in the investigated range of experimental conditions. The coefficient of variation of $6.0 \%$ (less than $10 \%$ ) indicated a high degree of precision and reliability of the model. The $p$-value $(0.0047)$ of the lack of fit indicated its significance, which was not desirable. This significant lack of fit could occur due to the small value of the mean square of pure error (0.58). Namely, the $F$-value of the lack of fit was obtained by dividing the mean square of the lack of fit by the mean square of the pure error, which may explain its high value. Therefore, a very good agreement between the values of the FAME content predicted by the developed regression model and the experimentally obtained values was confirmed by a small mean relative percentage deviation (MRPD) between them (5.2\%, 30 data), as can be observed in Figure 1. The Shapiro-Wilk test confirmed the normal distribution of residuals $(p>0.05)$, so there was no problem with the normality of the distribution of the experimental data (Figure 2). The values of Cook's distance, far less than the limit value (0.9), indicated no outliers in the tested dataset (Figure 3 ).

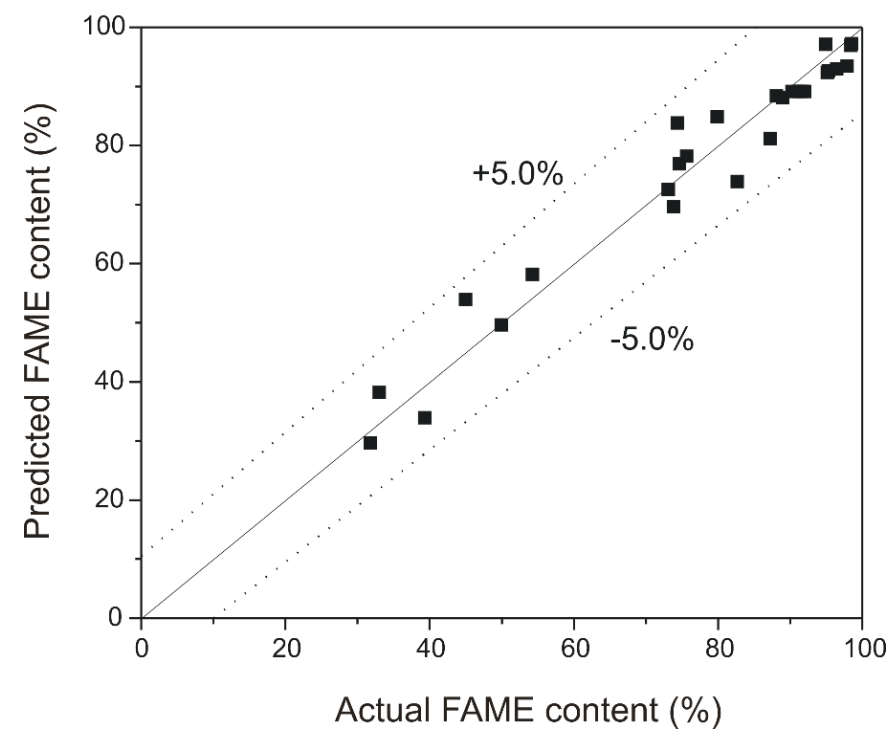

Figure 1 Comparison between predicted and experimental values of FAME content 


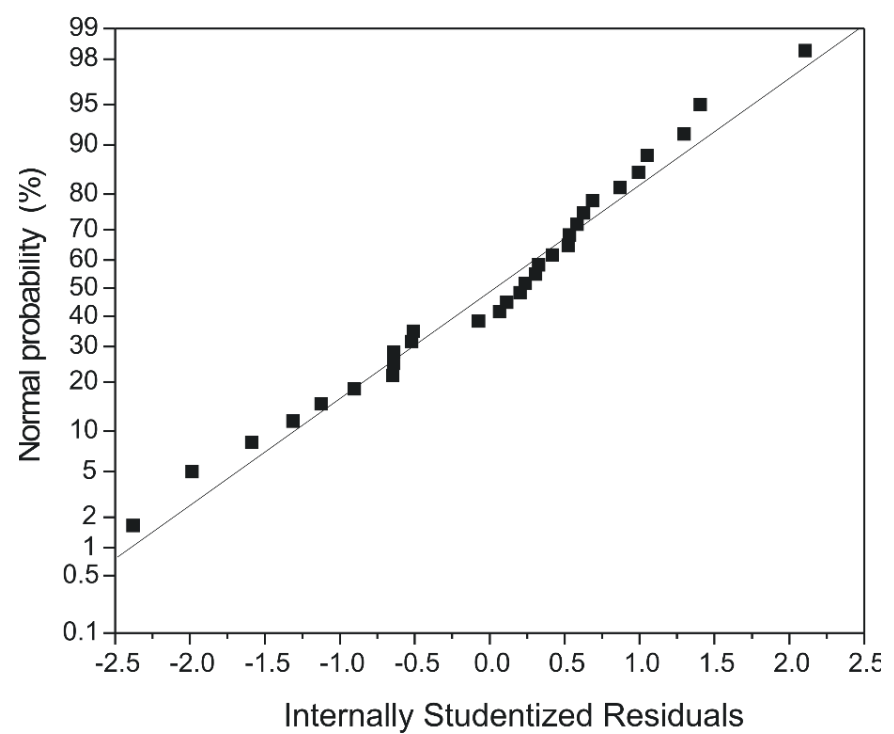

Figure 2 Estimation of residue distribution normality

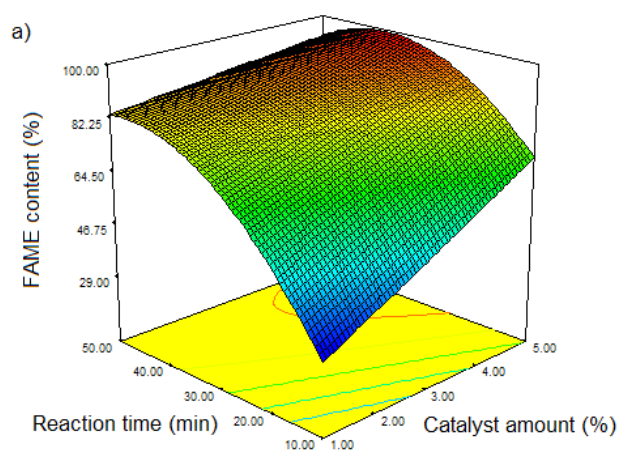

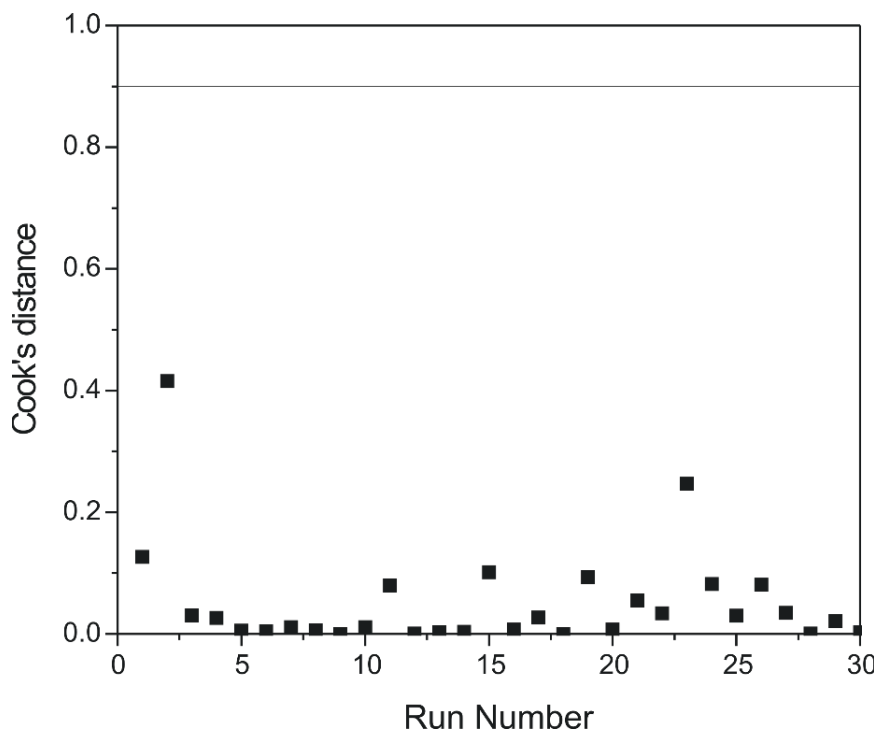

Figure 3 Cook's distance
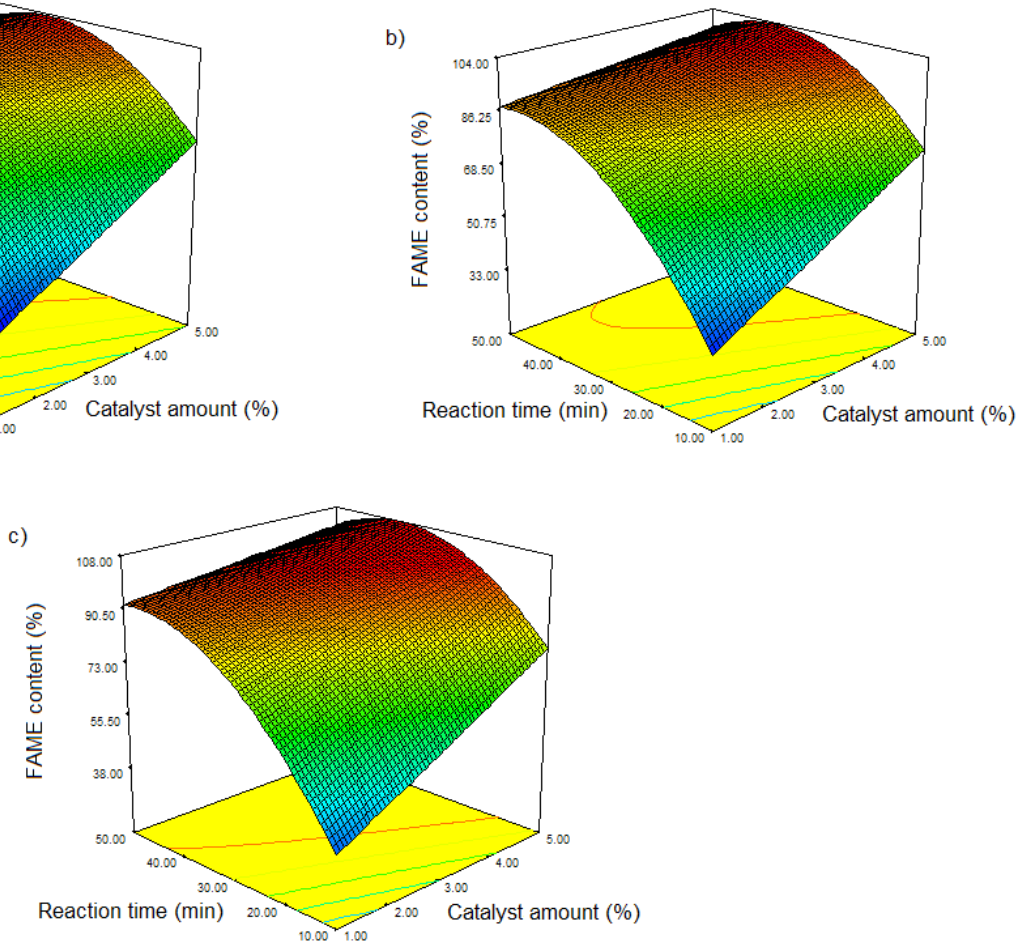

Figure 4 Response surface and contour plots for FAME content as a function of catalyst amount and reaction time at the methanol-to-oil molar ratio of $6: 1$ (a), 12:1 (b), and 18:1 (c)

Optimal reaction conditions

To visualize the optimal reaction conditions for achieving the maximum FAME content, the 3D response surface plots were applied (Figure $4 \mathrm{a}-\mathrm{c}$ ). The FAME content increases with increasing the amount of catalyst and the reaction time reaching a maximum. After that, a slight decrease in FAME content can be observed because of the reversible reaction that can occur at a prolonged re- action time and a larger amount of catalyst [28, 29]. The statistical influence of the methanol-to-oil molar ratio on FAME content is the smallest compared to the other two factors; its increase has a more pronounced positive effect at smaller amounts of the catalyst.

To choose the optimal reaction conditions and to reduce the cost of biodiesel production, it is necessary to decrease the required amount of methanol (methanol- 
to-oil molar ratio). Under the selected optimal conditions, i.e., the methanol-to-oil molar ratio of 10.34:1, the catalyst amount of $5 \%$, and the reaction time of $34 \mathrm{~min}$, the model predicts the FAME content of $99.6 \%$. This value agrees well with the experimentally obtained value $(97.2 \%)$. These optimal reaction conditions differ from those determined for the methanolysis of Bauhinia monandra oil over banana peels ash as a catalyst where the methanol-to-oil molar ratio and the catalyst amount were lower, but the reaction time was longer [21]. In the case of Calophyllum inophyllum oil methanolysis catalyzed by sugarcane leaf ash [15], the optimal methanol-to-oil molar ratio (19:1) and the reaction temperature $\left(64^{\circ} \mathrm{C}\right)$ were higher while the optimal catalyst amount was the same $(5 \%)$ as in the present study. When tucumã peels ash was used as a catalyst (1\%), the optimal methanol-to-oil molar ratio, reaction time, and temperature were 15:1, 4 $\mathrm{h}$, and $80^{\circ} \mathrm{C}$, respectively [30].

\section{Conclusions}

The statistical analysis of the methanolysis of USO with hazelnut shell ash as a catalyst showed that the reaction conditions (initial methanol-to-oil molar ratio, catalyst amount, and reaction time), as well as the twoparameter interaction of the catalyst amount and the reaction time, and the quadratic term of the reaction time, have a statistically significant effect on FAME content. The modified second-order polynomial model was used to optimize the reaction conditions. The validity of the developed model was confirmed by a low MRPD between the predicted and experimental data (5.2\%). The presented model is adequate, with normal distribution of the experimental data, and with no outliers in the tested dataset. According to this model, the predicted value of the maximum FAME content of $99.6 \%$ was achieved at the following optimal conditions: the initial methanol-tooil molar ratio of $10.34: 1$, the catalyst amount of $5 \%$, and the reaction time of $34 \mathrm{~min}$. Therefore, a high FAME content was obtained by the USO methanolysis catalyzed by hazelnut shell ash under moderate reaction conditions. The experimental value of FAME content (97.2\%) achieved under the optimal reaction conditions agreed well with the predicted one. A very good agreement between FAME content predicted by the developed regression model and the experimentally obtained values was confirmed by a small mean relative percentage deviation $(5.2 \%)$.

\section{Acknowledgments}

The present work has been funded by the Ministry of Education, Science and Technological development of the Republic of Serbia, Program for financing scientific research work, No.451-03-9/2021-14/200383, No.45103-9/2021-14/200133. It is also a part of the Project 0-14-18 of the SASA Branch in Niš, Serbia.

\section{References}

[1] S. Al-Zuhair, Production of biodiesel: possibilities and challenges, Biofuels, Bioproducts and Biorefining, 1 (2007) 57-66.

[2] A. Salis, M. Pinna, M. Monduzzi, V. Solinas, Biodiesel production from triolein and short chain alcohols through biocatalysis, Journal of Biotechnology, 119 (2005) 291299.

[3] A. E .Atabani, A. S.Silitonga, I. A. Badruddin, T. M. I. Mahlia, H. H. Masjukia, S. Mekhilefd, A comprehensive review on biodiesel as an alternative energy resource and its characteristics, Renewable and Sustainable Energy Reviews, 16 (2012) 2070-2093.

[4] I. B. Banković-llić, O. S. Stamenković, V. B. Veljković, Biodiesel production from non-edible plant oils, Renewable and Sustainable Energy Reviews, 16 (2012) 3621-3647.

[5] A. N. Phan, T. M. Phan, Biodiesel production from waste cooking oils, Fuel, 87 (2008) 3490-3496.

[6] M. R. Miladinović, I. Z. Lukić, O. S. Stamenković, V. B. Veljković, D. U. Skala, Heterogena bazno katalizovana metanoliza biljnih ulja: Presek stanja, Hemijska industrija, 64 (2010) 63-80.

[7] P. L. Boey, G. P. Maniam, S. A. Hamid, D. M. H. Ali, Utilization of waste cockle shell (Anadara granosa) in biodiesel production from palm olein: Optimization using response surface methodology, Fuel, 90 (2011) 23532358.

[8] N. Viriya-Empikul, P. Krasae, W. Nualpaeng, B. Yoosuk, K. Faungnawakij, Biodiesel production over Ca-based solid catalysts derived from industrial wastes, Fuel, 92 (2012) 239-244.

[9] F. Yaşar, Biodiesel production via waste eggshell as a low-cost heterogeneous catalyst: Its effects on some critical fuel properties and comparison with $\mathrm{CaO}$, Fuel, 255 (2019) 115828.

[10] A. Obadiah, G. A. Swaroopa, S. V. Kumar, K. R. Jeganathan, A. Ramasubbu, Biodiesel production from palm oil using calcined waste animal bone as catalyst, Bioresource Technology, 116 (2012) 512-516.

[11] S. M. Smith, C. Oopathum, V. Weeramongkhonlert, C. B. Smith, S. Chaveanghong, P. Ketwong, S. Boonyuen, Transesterification of soybean oil using bovine bone waste as new catalyst, Bioresource Technology, 143 (2013) 686-690.

[12] B. K. Uprety, W. Chaiwong, C. Ewelike, S. K. Rakshit, Biodiesel production using heterogeneous catalysts including wood ash and the importance of enhancing byproduct glycerol purity, Energy Conversion and Management, 115 (2016) 191-199.

[13] G. Pathak, D. Das, K. Rajkumari, L. Rokhum, Exploiting waste: Towards a sustainable production of biodiesel using: Musa acuminata peel ash as a heterogeneous catalyst, Green Chemistry, 20 (2018) 2365-2373.

[14] S. de S. Barros, W. A. G. Pessoa Junior, I. S. C. Sá, M. L. Takeno, F. X. Nobre, W. Pinheiro, L. Manzato, S. Iglauer, F. A. de Freitas, Pineapple (Ananás comosus) leaves ash as a solid base catalyst for biodiesel synthesis, Bioresource Technology, 312 (2020) 123569.

[15] A. Arumugam, P. Sankaranarayanan, Biodiesel production and parameter optimization: An approach to utilize residual ash from sugarcane leaf, a novel heterogeneous catalyst, from Calophyllum inophyllum oil, Renewable Energy, 153 (2020) 1272-1282. 
[16] A. Gouran, B. Aghel, F. Nasirmanesh, Biodiesel production from waste cooking oil using wheat bran ash as a sustainable biomass, Fuel, 295 (2021) 120542.

[17] M. R. Miladinović, M. V. Zdujić, D. N. Veljović, J. B. Krstić, I. B. Banković-llić, V. B. Veljković, O. S. Stamenković, Valorization of walnut shell ash as a catalyst for biodiesel production, Renewable Energy, 147 (2020) 1033-1043.

[18] S. V. Vassilev, C.G. Vassileva, Y.C. Song, W.Y. Li, J. Feng, Ash contents and ash-forming elements of biomass and their significance for solid biofuel combustion, Fuel, 208 (2017) 377-409.

[19] M. D. Kostić, A. Bazargan, O. S. Stamenković, V. B. Veljković, G. McKay, Optimization and kinetics of sunflower oil methanolysis catalyzed by calcium oxidebased catalyst derived from palm kernel shell biochar, Fuel, 163 (2016) 304-313.

[20] M. D. Kostić, M. B. Tasić, I. G. Đalović, M. O. Biberdžić, P. M. Mitrović, O. S. Stamenković, V. B. Veljković, Optimization of biodiesel production from corn oil by methanolysis catalyzed by corn cob ash, Recycling and Sustainable Development, 11 (2018) 53-62.

[21] E. Betiku, A. M. Akintunde, T. V. Ojumu, Banana peels as a biobase catalyst for fatty acid methyl esters production using Napoleon's plume (Bauhinia Monandra) seed oil: a process parameters optimization study, Energy, 103 (2016) 797-806.

[22] G. Dwivedi, M. P. Sharma, Application of Box-Behnken design in optimization of biodiesel yield from Pongamia oil and its stability analysis, Fuel, 145 (2015) 256-262.

[23] M. Karczewski, M. Marczak, P. Burmistrz, D. Makowska, Corrosive components of nutshells and their chars, E3S Web of Conferences 10, 00113, 2016.
[24] Y.S. M. Camacho, G. Mancini, F.A. Deorsola, D. Fino, Role of the particle size on the yield of hazelnut shell pyrolysis products, Conference proceedings, 6th International Conference on Sustainable Solid Waste Management, Naxos Island, Greece, 2018.

[25] H. Haykiri-Acma, The role of particle size in the nonisothermal pyrolysis of hazelnut shell, Journal of Analitical and Applied Pyrolysis, 75 (2006) 211-216.

[26] M.R. Miladinović, O.S. Stamenković, V.B. Veljković, U.D. Skala, Continuous sunflower oil methanolysis over quicklime in a packed-bed tubular reactor, Fuel, 154 (2015) 301-307.

[27] N. Subramonia Pillai, P. Seeni Kannan, S. C. Vettivel, S. Suresh, Optimization of transesterification of biodiesel using green catalyst derived from Albizia Lebbeck Pods by mixture design, Renewable Energy, 104 (2017) 185196.

[28] M. O. Daramola, K. Mtshali, L. Senokoane, O. M Fayemiwo, Influence of operating variables on the transesterification of waste cooking oil to biodiesel over sodium silicate catalyst: A statistical approach, Journal of Taibah University for Science, 10 (2016) 675-684.

[29] T. Eevera, K. Rajendran, S. Saradha, Biodiesel production process optimization and characterization to assess the suitability of the product for varied environmental conditions, Renewable Energy, 34 (2009) 762-765.

[30] I. M. Mendonça, O. A. R. L. Paes, P. J. S. Maia, M. P. Souza, R. A. Almeida, C. C. Silva, S. Duvoisin Jr., F. A. de Freitas. New heterogeneous catalyst for biodiesel production from waste tucumã peels (Astrocaryum aculeatum Meyer): Parameters optimization study, Renewable Energy, 130 (2019) 103-110.

\section{Izvod \\ OPTIMIZACIJA METANOLIZE KORIŠĆENOG SUNCOKRETOVOG ULJA KATALIZOVANE PEPELOM LJUSKE LEŠNIKA}

Milica Petković ${ }^{\text {, Marija Miladinović }}{ }^{3}$, Ivana Banković-llić2 ${ }^{2}$ Olivera Stamenković2 Vlada Veljković 2,3

\footnotetext{
${ }^{1}$ Stipendista Ministarstva prosvete, nauke i tehnološkog razvoja Republike Srbije

${ }^{2}$ Tehnološki fakultet, Univerzitet u Nišu, Leskovac, Srbija

${ }^{3}$ Poljoprivredni fakultet, University of Niš, Kruševac, Srbija

${ }^{4}$ Srpska akademija nauka i umetnosti, Beograd, Srbija
}

U radu je izvršeno istraživanje metanolize korišćenog suncokretovog ulja pomoću pepela ljuske lešnika kao katalizatora radi procene statističke značajnosti procesnih faktora, tj. početnog molskog odnosa metanol:ulje, količine katalizatora i vremena reakcije na sintezu metil estara masnih kiselina (MEMK), kao i odredjivanja njihovih optimalnih vrednosti. Reakcija metanolize je izvedena u šaržnom reaktoru pri početnom molskom odnosu metanol:ulje 6:1-18:1, količini katalizatora 1-5 \% (u odnosu na masu ulja) i vremenu reakcije 10-50 min. Statističko modelovanje i optimizacija izvedeni su primenom modifikovane polinomne jednačine drugog reda koja je razvijena metodom površine odziva u kombinaciji sa punum faktorijelnim planom $3^{3}$ sa tri centralne tačke. Primenom analize varijansi (ANOVA) pokazano je da sva tri faktora, kao i dvoparametarska interakcija količine katalizatora sa vremenom reakcije, i kvadrat vremena reakcije imaju statistički značajan uticaj na sadržaj MEMK. Optimalni uslovi izvodjenja reakcije su: molski odnos metanol:ulje 10,34:1, količina katalizatora 5\% i vreme reakcije $34 \mathrm{~min}$. Predviđena vrednost sadržaja metil estara $(99,63 \%)$ dobro se slaže sa eksperimentalno određenom vrednošću $(97,15 \%)$.
(ORIGINALNI NAUČNI RAD) UDK 662.756.3:66.011 DOI $10.5937 /$ savteh2102032P

Ključne reči: biodizel; ljuska lešnika; modelovanje, optimizacija, metoda površine odziva 